\title{
Effect of blanching, acid type, and temperature on the extraction of anthocyanin from Tibouchina semidecandra flower
}

\author{
${ }^{1}$ Daniella, S., ${ }^{2}$ Kartawiria, I.S. and ${ }^{1, *}$ Marpaung, A.M. \\ ${ }^{I}$ Department of Food Technology, Faculty of Life Sciences and Technology, Swiss German University, \\ Tangerang Indonesia \\ ${ }^{2}$ Department of Chemical Engineering, Faculty of Life Sciences and Technology, Swiss German University, \\ Tangerang Indonesia
}

\author{
Article history: \\ Received: 24 December 2020 \\ Received in revised form: 9 \\ February 2021 \\ Accepted: 22 May 2021 \\ Available Online: 5 \\ December 2021
}

Keywords:

Anthocyanin,

Extraction,

Tibouchina semidecandra,

Phenolic content

DOI:

https://doi.org/10.26656/fr.2017.5(6).770

\begin{abstract}
Extraction is the most common way to obtain anthocyanins from their natural matrices. During the extraction, the anthocyanin may degrade due to the heat and acidic solvent. The objectives of this research were to determine the best acidic aqueous solution and temperature to extract anthocyanin from Tibouchina semidecandra flower and to decide if the blanching process has a significant effect on the extracted anthocyanin. The $T$. semidecandra petals were separated into two groups: steam blanched for 6 mins and without blanching. Both were dried for $24 \mathrm{hrs}$ at $45^{\circ} \mathrm{C}$ and powdered. The extract was prepared by macerating the powdered petal into $\mathrm{pH} 3$ aqueous solutions made of three different acids (citric, malic, and hydrochloric acid, respectively) in a water bath shaker at various temperatures $\left(30,45,60\right.$, and $\left.75^{\circ} \mathrm{C}\right)$ for an hour. The extracts were then filtered, centrifuged, and analysed for their colour intensity, browning index, monomeric anthocyanin, polymeric anthocyanin, and total phenolic content. The best method to obtain the highest colour intensity, monomeric anthocyanin, total phenolic content, and lowest browning index was using steam-blanched dried petal, citric or malic acid as solvent and extraction temperature at $60^{\circ} \mathrm{C}$. The total monomeric anthocyanin and phenolic content of the extract was $3.63 \pm 0.35 \mathrm{mg} / \mathrm{g}$ dried petal and $74.47 \pm 11.47 \mathrm{mg} / \mathrm{g}$ dried petal, respectively.
\end{abstract}

\section{Introduction}

The potential adverse health effect of a long-period consumption of artificial colourant in food to the human body increased the demand for natural pigment. Anthocyanins are amongst the most potent natural food colourants that also provide health benefits to the human body. These pigments are water-soluble and exhibit a wide range of colours from red to blue, depending on their chemical structure and $\mathrm{pH}$.

The stability of anthocyanins is affected by several factors, particularly $\mathrm{pH}$ and heat. The colour may also be interfered by the brown colour due to the activity of the polyphenol oxidase enzyme (Patras et al., 2010). A mild heating treatment was reported to inactivate the enzyme. However, the heat exposure during blanching could probably decrease the anthocyanin content (Patras et al., 2010).

Lasiandra (Tibouchina semidecandra L.) is an ornamental shrub producing dark purple flowers that are also used traditionally in medicine and food (Janna and
Khairul, 2007). The flower was reported to have a monoacylated anthocyanin identified as malvidin-3(pcoumarylglucoside)-5-glucoside (Lowry, 1976). Anthocyanins containing acyl groups are more stable than those with no acyl group (Marpaung et al., 2015). Janna and Khairul (2007) reported that the anthocyanin from $T$. semidecandra was relatively stable at $\mathrm{pH} 3$ or below. Meanwhile, Sun et al. (2011) described that the anthocyanin degradation at a high acidic condition was initiated by the hydrolysis of the anthocyanin to its aglycon. Hypothetically, the strong acid would cause more severe hydrolysis than the weak acid.

Referring to the background, we considered that the application of blanching, different acid types and elevated temperature was necessary to be studied to obtain the best extraction parameter of anthocyanin from $T$. semidecandra. The colour intensity, browning index, total monomeric, percentage of polymeric anthocyanin, and total phenolic content were measured to the quality of the anthocyanin extracts. 


\section{Materials and methods}

\subsection{Material}

Tibouchina semidecandra petals (TS) were gathered from Taman Nasional Gunung Salak-Halimun, West Java, Indonesia. The petals were divided into two, one underwent the steam blanching process for 6 minutes (Marpaung et al., 2013) and the rest was left without blanching. Both blanched and non-blanched petals were dried in an oven (Daihan Wiseven, Korea) for about 24 hrs at $45^{\circ} \mathrm{C}$. The dried petals are powdered and kept in a freezer until used. Hydrochloric acid, potassium chloride, sodium carbonate, Folin-Ciocalteau reagent, gallic acid, were obtained from Merck ${ }^{\circledR}$ (Germany). The reagents were analytical grade. Citric acid and malic acid were food-grade (Brataco, Indonesia).

\subsection{Extraction}

The extraction was done by macerating the powdered petals in three types of acidified distilled water $\mathrm{pH} 2$ (citric acid, malic acid, and hydrochloric acid) at various temperatures $\left(30,4560\right.$, and $\left.75^{\circ} \mathrm{C}\right)$ for an hour with continuous shaking and without the presence of light. The volume of solvents was $40 \mathrm{~mL}$ per $1 \mathrm{~g}$ powdered petal. The extract was filtered using filter clothe, then centrifuged at $7000 \mathrm{rpm}$ at $25^{\circ} \mathrm{C}$ for 5 mins. The colour quality, monomeric anthocyanin content, polymeric anthocyanin, and total phenolic content of every treatment were determined.

\subsection{Colour quality}

The colour quality of an anthocyanin source extract was commonly measured by its colour intensity (CI) and browning index (BI) (Marpaung et al., 2019). The wavelength giving the highest absorbance $\left(\lambda_{\max }\right)$ at visible light region of the extract was determined by a UV-Vis spectrophotometer (Genesys 10uv Thermo Electron Corporation, USA). The CI of the extract calculated as follow:

$\mathrm{CI}=\left(\mathrm{A}_{\lambda \max }-\mathrm{A}_{700}\right) \times \mathrm{DF}$

Meanwhile, the BI determined as follow:

$\mathrm{BI}=\left(\mathrm{A}_{420}-\mathrm{A}_{700}\right) /\left(\mathrm{A}_{\lambda \max }-\mathrm{A}_{700}\right)$

Where $A_{\lambda \max }$ is the absorbance at $\lambda_{\max }, A_{420}$ is the absorbance at $420 \mathrm{~nm}, \mathrm{~A}_{700}$ is the absorbance at $700 \mathrm{~nm}$, and $\mathrm{DF}$ is a dilution factor.

\subsection{Total monomeric anthocyanin}

The total monomeric anthocyanin (AM) was determined by the $\mathrm{pH}$ differential method (Marpaung et $a l ., 2013)$ and calculated as malvidin-3-glucoside. The principle of the method was by measuring the highest absorbance at the visible light region (absorbance at $\lambda_{\max }$ ) of the extract at $\mathrm{pH} 1$ and 4.5 using a UV-Vis spectrophotometer. At $\mathrm{pH} \mathrm{1,} \mathrm{the} \mathrm{only} \mathrm{species} \mathrm{that} \mathrm{existed}$ in an anthocyanin was red flavylium cation $\left(\mathrm{AH}^{+}\right)$. Meanwhile, at $\mathrm{pH} 4.5$ the predominant species was colourless hemiketal (B). The colour appeared at $\mathrm{pH} 4.5$ representing the degraded anthocyanins in the polymeric form that are resistant to colour change with a change in $\mathrm{pH}$. Hence, the difference between the absorbance at $\mathrm{pH}$ 1 and 4.5 represent the intensity of the monomeric anthocyanin.

$$
A=\left(A_{\lambda \max }-A_{700}\right)_{\mathrm{pH} 1.0}-\left(\mathrm{A}_{\lambda \max }-\mathrm{A}_{700}\right)_{\mathrm{pH} 4.5}
$$

By using the following formula the total monomeric anthocyanin in the extract $(\mathrm{mg} / \mathrm{L})$ could be determined.

$\mathrm{AM}=(\mathrm{A} \times \mathrm{MW} \times \mathrm{DF} \times 1000) /(\varepsilon \times 1)$

Where MW is the molecular weight of malvidin-3glucoside (493.2) $\mathrm{g} / \mathrm{mol}$ ), DF is a dilution factor, $\varepsilon$ is the molar absorptivity of malvidin-3-glucoside (28000), and 1 is the cuvette width $(1 \mathrm{~cm})$.

\subsection{Polymeric anthocyanin}

The percentage of polymeric anthocyanin (AP) was measured by treating the sample with sodium metabisulphite (Brownmiller et al., 2008). A polymeric anthocyanin is resistant to bleaching by bisulphite, on the other hand, the monomeric anthocyanins will be bleached and become colourless.

Each $2.8 \mathrm{~mL}$ of sample was put into two cuvettes. Then $0.2 \mathrm{~mL}$ of bisulphite was added into one cuvette, and as the control sample, $0.2 \mathrm{~mL}$ of distilled water was added into another cuvette. Then the mixtures were equilibrated for 15 mins. The absorbance of each sample was measured using a spectrophotometer at $420 \mathrm{~nm}, \lambda_{\max }$, and $700 \mathrm{~nm}$. The colour density of the control sample was calculated as follow:

$$
\begin{aligned}
& \text { Colour density }=\left[\left(\mathrm{A}_{420}-\mathrm{A}_{700}\right)+\left(\mathrm{A}_{\lambda \max }-\mathrm{A}_{700}\right)\right] \times \\
& \text { Dilution factor }
\end{aligned}
$$

The polymeric anthocyanin content was calculated as follow:

$$
\begin{aligned}
& \text { Polymeric colour }=\left[\left(\mathrm{A}_{420}-\mathrm{A}_{700}\right)+\left(\mathrm{A}_{\lambda \max }-\mathrm{A}_{700}\right)\right] \times \\
& \text { Dilution factor }
\end{aligned}
$$

The percentage of polymeric colour is calculated as follow:

$$
\mathrm{AP}=(\text { Polymeric colour }) /(\text { Colour density }) \times 100
$$

\subsection{Total phenolic content}

The Folin-Ciocalteau method was used to measure the total phenolic content (TP) of the extracts and stated as the gallic acid equivalent (GAE) (Marpaung et al., 2013). A $0.2 \mathrm{~mL}$ extract was added to $0.8 \mathrm{~mL}$ of $20 \%$ 
$\mathrm{Na}_{2} \mathrm{CO}_{3}$ and $1 \mathrm{~mL}$ Folin-Ciocalteau reagent. The mixture was left for one hour, then the absorbance was measured at $765 \mathrm{~nm}$. The standard curve was developed by the reaction of $0.2 \mathrm{~mL}$ gallic acid at several levels of concentration with $0.8 \mathrm{~mL}$ of $20 \% \mathrm{Na}_{2} \mathrm{CO}_{3}$ and $1 \mathrm{~mL}$ Folin-Ciocalteau reagent. The TP was calculated as follow.

$\mathrm{TP}(\mathrm{mg} / \mathrm{L} \mathrm{GAE})=\mathrm{Abs} / \mathrm{m}$

Where Abs is the absorbance (A) and $\mathrm{m}$ is the slope of the gallic acid standard curve.

\subsection{Statistical analysis}

Statistical analyses involved in this experiment were 3 ways Analysis of Variance (ANOVA) (Design-Expert ${ }^{\circledR}$ version 7.0.0., Stat-Ease, Inc., Minneapolis, USA) and followed by Tukey HSD test for the posthoc analysis (OpenStat ${ }^{\circledR}$ version 11.9.08).

\section{Results and discussion}

Total monomeric anthocyanin of all TS extracts studied ranged from 26.77 to $103.13 \mathrm{mg}$ per litre or equal to 1.07 to $4.13 \mathrm{mg} / \mathrm{g}$ dried petal. The colour intensity and browning index of TS extracts were 2.28 to 10.72 and 0.36 to 0.69 , respectively. The total phenolic content of TS extracts was $810.21-2234.41 \mathrm{mg} / \mathrm{L}$ GAE or equal to $32.41-89.38 \mathrm{mg} / \mathrm{g}$ dried petal. The percentage of polymeric anthocyanin fraction in the TS extracts was $20.19-27.09 \%$.

\subsection{Effect of blanching of the petal prior to drying}

The blanching process was applied to the flower before drying to avoid the brown colour development due to the activity of the polyphenol oxidase enzyme (Marpaung et al., 2013). On the other hand, the heat applied during blanching damage the cell wall of the flower to increase the yield of the anthocyanin extracted (Marpaung et al., 2013; Liu et al., 2015; Deylami et al., 2016; Mahmudatussa'adah et al., 2019). In short, blanching is often to be applied to increase the colour quality of an anthocyanin source extract.

As seen in Figure 1, the blanching increased the colour quality of TS extract by giving significant higher $\mathrm{CI}$ and lower BI (the p-value was 0.0006 and 0.0015 , respectively). Browning index was calculated by dividing the absorbance at $420 \mathrm{~nm}\left(\mathrm{~A}_{420}\right)$ to the absorbance at $\lambda_{\max }$ $\left(\mathrm{A}_{\lambda \max }\right)$. The $\mathrm{A}_{420}$ of blanched and non-blanched extracts was not significantly different. Therefore, the higher BI in non-blanched extracts was contributed only by their lower CI. Hence, the six minutes of steam blanching prior to drying improve the effectivity of the extraction, but was not significant to avoid browning.
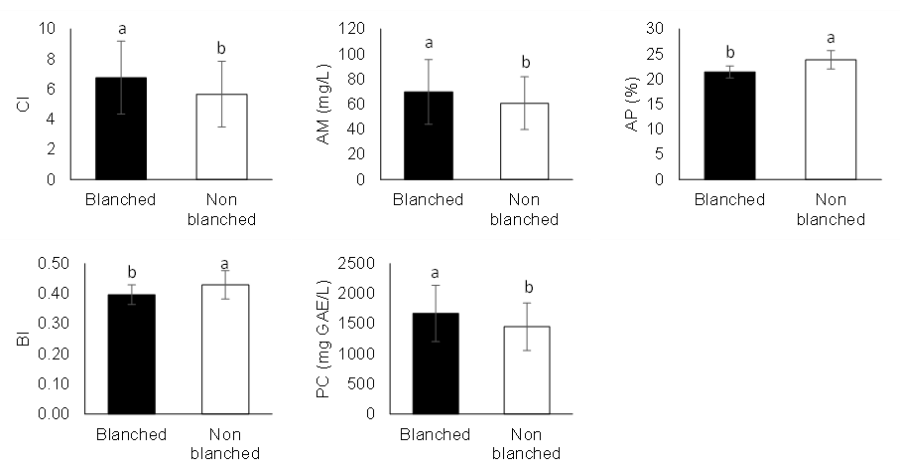

Figure 1. The effect of blanching process to the colour intensity (CI), monomeric and polymeric Anthocyanin (AM and $\mathrm{AP}$, respectively), browning index (B)) and total phenolic content (PC) of the extract of $T$. semidecandra flower. Bars with the same notations in the same graph are not significantly different $(\alpha=0.05)$.

A wide variation of the duration of steam blanching to inactivate polyphenol oxidase has been reported. Li et al. (2019) reported that one-minute steam blanching is adequate to inactivate almost $100 \%$ of polyphenol oxidase in the Chrysanthemum indicum flower. CevallosCasals and Cisneros-Zevallos (2004) stated that 10 mins steam blanching is needed to ensure inactivation of polyphenol oxidase in Andean purple corn and redfleshed sweet potato. Zhang et al. (2011) reported that the inactivation of polyphenol oxidase of Echinacea purpurea roots was achieved by steam blanching for 15 mins. Hence, further study to obtain the best time to avoid browning in TS flowers is needed.

Besides increasing the colour quality, blanching also increased the potentiality of TS extract as the bioactive compound source by yielding higher anthocyanin and phenolic content (the p-value was 0.0102, and 0.0467, respectively). Meanwhile, the blanched sample had a lower percentage of polymeric anthocyanin ( $\mathrm{p}$-value = 0.0003 ), which could be because of the increase in the colour intensity.

\subsection{Effect of acid type}

Figure 2 shows that weak acid (citric acid and malic acid) was better to extract the anthocyanin from $T$. semidecandra petal. A similar result for different anthocyanin source extracts like Berberis vulgaris, Solanum melongena, Brassica oleracea (Hosseini et al., 2016), Carissa carandas (Le et al., 2016) and Ficus carica L. (Meziant et al., 2018) was also recommended previously.

The CI of the anthocyanin extracted by hydrochloric acid (HA-extract) was significantly lower than the CI of anthocyanin extracted with citric and malic acid (CAextract and MA extract, respectively). Hydrochloric acid is an effective solvent to extract anthocyanin (Hosseini et al., 2016). However, it also tends to degrade most organic 
compounds (Hosseini et al., 2016). Therefore, the lower CI of HA-extract was probably because of the degradation of the anthocyanin. This probability is supported by the two other characteristics of HA extract: lower AM and lower TP content.
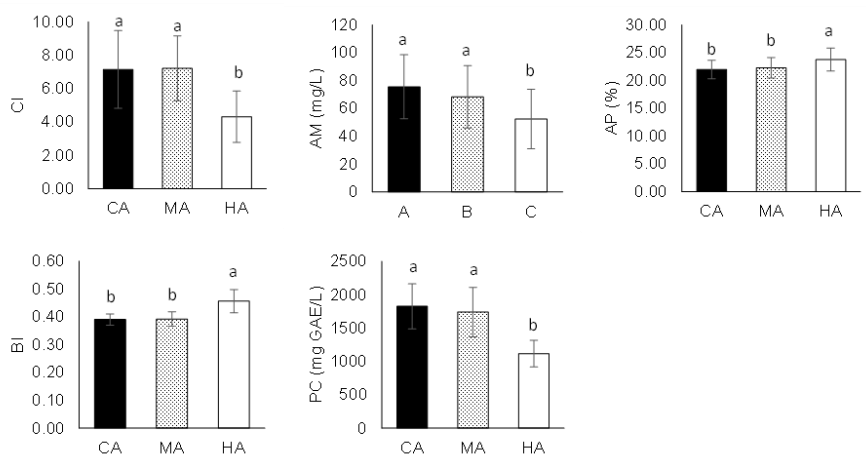

Figure 2. The effect of acid type $(\mathrm{CA}=$ citric acid, $\mathrm{MA}=$ malic acid, HA = hydrochloric acid) in the extraction solvent to the colour intensity $(\mathrm{CI})$, monomeric and polymeric Anthocyanin (AM and AP, respectively), browning index (B)) and total phenolic content (PC) of the extract of $T$. semidecandra flower. Bars with the same notations in the same graph are not significantly different $(\alpha=0.05)$.

Marpaung et al. (2019) described that the anthocyanin degradation initiated by the hydration of the red colour species (flavylium cation) to colourless species (hemiketal), indicated by the decrease of colour intensity. In the extract extracted by a weak acid, the hydration might be blocked because of the citric acid that chelates anthocyanin and builds copigmentation that stabilise the colour (Hosseini et al., 2016). The work of malic acid to configure copigmentation with anthocyanin was also evident (Munawaroh et al., 2016). The next step of anthocyanin degradation is the tautomerization of colourless species to pale yellow species, known as chalcone. The degradation is indicated by the increase of BI. As shown in Figure 2, a significant increase of BI was observed in HA extract.

The colourless hemiketal and chalcone were anthocyanin and calculated in the total monomeric anthocyanin determination. Hence, the decrease in colour intensity was not always mean the decrease of total monomeric anthocyanin. However, this study showed that the AM in HA extract was significantly lower than the AM in CA and MA extract. This result indicated that during the extraction by hydrochloric acid apart of anthocyanin in TS degraded further to simple products like benzaldehyde and benzoic acid derivatives (Marpaung et al., 2017b). Because of the degradation, the total phenolic content in HA extracts also decreased.

\subsection{Effect of temperature}

Heat is the energy commonly applied to release bioactive compounds like anthocyanins from their natural matrices. However, heat is also a significant factor that may degrade anthocyanin. Therefore, the extraction of anthocyanin from a plant at a moderate temperature reported to be the best.

Wang et al. (2016) reported that the optimum parameters to extract anthocyanin from blueberries, and red pear peels are $50^{\circ} \mathrm{C}$ for an hour. Marpaung et al. (2013) reported that extraction at $60^{\circ} \mathrm{C}$ for 30 mins is optimum to extract the anthocyanins from Clitoria ternatea petal. With microwave-assisted extraction, the best condition to extract anthocyanins from blueberry powder is at $47^{\circ} \mathrm{C}$ for 7 minutes (Zheng et al., 2013). The use of higher temperature and longer time $\left(70^{\circ} \mathrm{C}\right.$ for 2 hours) are reported to extract anthocyanin from black rice bran (Kim et al., 2015).

The optimum extraction of the anthocyanin from the TS petal was also achieved by applying a moderate heat treatment. As seen in Figure 3, the highest CI, AM, and TP of TS extract were yielded through the extraction at 60 and $75^{\circ} \mathrm{C}$ for an hour. There was no significant difference in colour intensity and anthocyanin content caused by the two temperatures. Hence, $60^{\circ} \mathrm{C}$ was preferred because of the lower energy consumption.
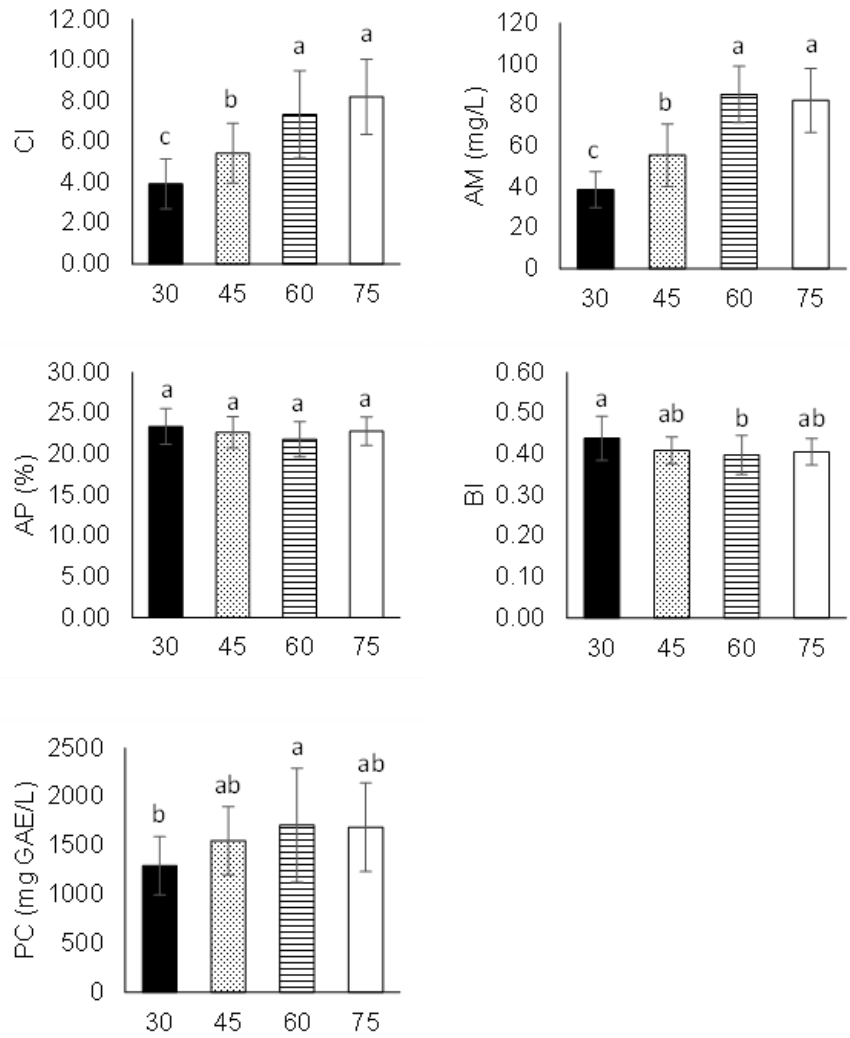

Figure 3. The effect of extraction temperature to the colour intensity (CI), monomeric and polymeric Anthocyanin (AM and $\mathrm{AP}$, respectively), browning index (B)) and total phenolic content (PC) of the extract of $\mathrm{T}$. semidecandra flower. Bars with the same notations in the same graph are not significantly different $(\alpha=0.05)$ 


\subsection{Best extraction parameter}

With the help of Design-Expert software, the best extraction condition to obtain the highest colour intensity, total monomeric anthocyanin and total phenolic content were determined. The chosen process was blanching prior to drying, the use of citric acid or malic acid as solvent and $60^{\circ} \mathrm{C}$ as the temperature of the extraction. The predicted quality of the extract is listed in Table 1.

The CI and BI of TS extract were relatively comparable to the $\mathrm{CI}$ and $\mathrm{BI}$ of the various plant extract like Clitoria ternatea, Melastoma malabathricum, Rhodomyrtus tomentosa and Bauhinia purpurea (Marpaung et al., 2015; Marpaung et al., 2017a). For the AM, TS extract showed a higher content of AM than the extract of eggplant $(1.38 \mathrm{mg} / \mathrm{g}$ dried petal) (Dranca and Oroian, 2016), red cabbage $(0.3 \mathrm{mg} / \mathrm{g}$ dried leaves $)$ (Oroian et al., 2017). However, the AM of TS extract was lower than the AM of blueberry $(8.09 \mathrm{mg} / \mathrm{g}$ dried fruit) (Darniadi et al., 2019). The percentage of polymeric anthocyanin fraction in the TS extract was relatively close to the percentage of polymeric anthocyanin of other anthocyanin source extract, like black carrot juice (15.66 to $22.32 \%$ ) (Türkyılmaz et al., 2012) and strawberry pulps (22.61 - 29.25\%) (Cao et al., 2011). The phenolic content of TS extracts was higher than the phenolic content of blueberry g (Darniadi et al., 2019), eggplant peel (Dranca and Oroian, 2016) and red cabbage (Oroian et al., 2017).

Table 1. Quality of the extract of blanched Tibouchina semidecandra petal powder extracted by citric acid at $\mathrm{pH} 2$, $60^{\circ} \mathrm{C}$ for an hour

\begin{tabular}{lcc}
\hline Quality Parameter & Unit & $\begin{array}{c}\text { Value } \\
\text { (Mean } \pm 95 \% \\
\text { confidence interval) }\end{array}$ \\
\hline Colour intensity & $\begin{array}{c}\text { Absorbance Unit } \\
\text { (AU) }\end{array}$ & $7.70 \pm 0.73$ \\
Browning index & $\mathrm{mg} / \mathrm{L}$ & $0.39 \pm 0.024$ \\
$\begin{array}{l}\text { Total monomeric } \\
\text { anthocyanin }\end{array}$ & $\mathrm{mg} / \mathrm{g}$ dry petal & $90.75 \pm 8.69$ \\
$\begin{array}{l}\text { Polymeric } \\
\text { anthocyanin }\end{array}$ & $\%$ & $3.63 \pm 0.35$ \\
Total phenolic & $\mathrm{mg} / \mathrm{L}$ & $1861.93 \pm 286.80$ \\
content & $\mathrm{mg} / \mathrm{g}$ dry petal & $74.47 \pm 11.47$ \\
\hline
\end{tabular}

\section{Conflict of interest}

The authors declare no conflict of interest.

\section{References}

Brownmiller, C., Howard, L. and Prior, R. (2008). Processing and storage effects on monomeric anthocyanins, percent polymeric colour, and antioxidant capacity of processed blueberry products. Journal of Food Science, 73(5), H72-H79. https://doi.org/10.1111/j.1750-3841.2008.00761.x
Cao, X., Zhang, Y., Zhang, F., Wang, Y., Yi, J. and Liao, $X$. (2011). Effects of high hydrostatic pressure on enzymes, phenolic compounds, anthocyanins, polymeric colour and colour of strawberry pulps. Journal of the Science of Food and Agriculture, 91 (5), 877-885. https://doi.org/10.1002/jsfa.4260

Cevallos-Casals, B.A. and Cisneros-Zevallos, L. (2004). Stability of anthocyanin-based aqueous extracts of Andean purple corn and red-fleshed sweet potato compared to synthetic and natural colourants. Food Chemistry, 86(1), 69-77. https://doi.org/10.1016/ j.foodchem.2003.08.011

Darniadi, S., Ifie, I. and Ho, P.M. (2019). Evaluation of total monomeric anthocyanin, total phenolic content and individual anthocyanins of foam-mat freezedried and spray-dried blueberry powder. Journal of Food Measurement and Characterization, 13(2), 1599-1606. https://doi.org/10.1007/s11694-01900076-w

Deylami, M.Z., Rahman, R.A., Tan, C.P., Bakar, J. and Olusegun, L. (2016). Effect of blanching on enzyme activity, colour changes, anthocyanin stability and extractability of mangosteen pericarp: A kinetic study. Journal of Food Engineering, 178, 12-19. https://doi.org/10.1016/j.jfoodeng.2016.01.001

Dranca, F. and Oroian, M. (2016). Optimization of ultrasound-assisted extraction of total monomeric anthocyanin (TMA) and total phenolic content (TPC) from eggplant (Solanum melongena L.) peel. Ultrasonics Sonochemistry, 31, 637-646. https:// doi.org/10.1016/j.ultsonch.2015.11.008

Hosseini, S., Gharachorloo, M., Ghiassi-Tarzi, B. and Ghavami, M. (2016). Evaluation of the organic acids ability for extraction of anthocyanins and phenolic compounds from different sources and their degradation kinetics during cold storage. Polish Journal of Food and Nutrition Science, 66(4), 261269. https://doi.org/10.1515/pjfns-2015-0057

Janna, O. and Khairul, A. (2007). Anthocyanin stability studies in Tibouchina semidecandra L. Food Chemistry, 101(4), 1640-1646. https:// doi.org/10.1016/j.foodchem.2006.04.034

Kim, H.J., Wee, J.-H. and Yang, E.J. (2015). Optimal conditions for anthocyanin extraction from black rice bran and storage stability of anthocyanin extract. Journal of the Korean Society of Food Science and Nutrition, 44(10), 1543-1549. https:// doi.org/10.3746/jkfn.2015.44.10.1543

Le, X.T., Huynh, M.T., Pham, T.N., Than, V.T., Toan, T.Q., Bach, L.G. and Trung, N.Q. (2016). Optimization of total anthocyanin content, stability and antioxidant evaluation of the anthocyanin extract from vietnamese Carissa carandas L. fruits. 
Processes, 7(468), 1-15. https://doi.org/10.3390/ pr7070468

Li, Y.-H., Wu, Z.-F., Wang, X.-C., and Ming Yang, F.Y. (2019). Effects of combined infrared and steam blanching on enzyme inactivation and product quality of Chrysanthemum indicum L. flower. Journal of Food Processing and Preservation, 43 (10), e14119. https://doi.org/10.1111/jfpp.14119

Liu, P., Mujumdar, A.S., Zhang, M. and Jiang, H. (2015). Comparison of three blanching treatments on the colour and anthocyanin level of the microwaveassisted spouted bed drying of purple flesh sweet potato. Drying Technology, 33(1), 66-71. https:// doi.org/10.1080/07373937.2014.936558

Lowry, J. (1976). Anthocyanins of the Melastomataceae, Myrtaceae and some allied families. Phytochemistry, 15(4), 513-516. https://doi.org/10.1016/S0031-9422 (00)88960-8

Mahmudatussa'adah, A., Patriasih, R., Maulani, R.R. and Nurani, A.S. (2019). Effect of blanching pretreatment on colour and anthocyanin of dried slice purple sweet potato (Ipomoea batatas L). Journal of Physics: Conference Series, 1402(5), 1-5. https:// doi.org/10.1088/1742-6596/1402/5/055080

Marpaung, A.M., Andarwulan, N. and Prangdimurti, E. (2013). The optimization of anthocyanin pigment extraction from butterfly pea (Clitoria ternatea L.) petal using Response Surface Methodology. Acta Horticulturae, 1011(1011), 205-211. https:// doi.org/10.17660/ActaHortic.2013.1011.24

Marpaung, A.M., Andarwulan, N., Hariyadi, P. and Faridah, D.N. (2015). Spectral Characteristics and Colour Stability of Melastomataceae and Clitoria ternatea L. Extracts, presented at the $17^{\text {th }}$ Food Innovation Asia Conference. Bangkok.

Marpaung, A.M., Andarwulan, N., Hariyadi, P. and Faridah, D.N. (2017a). Study on Spectral Characteristics of Selected Unacylated, Monoacylated and Polyacylated Anthocyanin Source Plant Extract at Various pH, presented at the 15th ASEAN Conference on Food Science and Technology, p. 234-240. Ho Chi Minh City, Vietnam

Marpaung, A.M., Andarwulan, N., Hariyadi, P. and Faridah, D.N. (2017b). The colour degradation of anthocyanin-rich extract from butterfly pea (Clitoria ternatea L.) petal in various solvents at $\mathrm{pH} 7$. Natural Product Research, 31(6), 2273-2280. https:// doi.org/10.1080/14786419.2017.1303689

Marpaung, A.M., Zhang, I. and Sutanto, H. (2019). Colour behaviour and stability of anthocyanin in the blue flower of Stachytarpheta jamaicensis and Hydrangea macrophylla. IOP Conference Series:
Materials Science and Engineering, 532(1), 012015. https://doi.org/10.1088/1757-899X/532/1/012015

Meziant, L., Boutiche, M., Bey, M.B., Saci, F. and Louaileche, H. (2018). Standardization of monomeric anthocyanins extraction from fig fruit peels (Ficus carica L.) using single factor methodology. Journal of Food Measurement and Characterization, 12(2), 2865-2873. https:// doi.org/10.1007/s11694-018-9901-6

Munawaroh, H., Fadillah, G., Saputri, L.N., Hanif, Q.A., Hidayat, R. and Wahyuningsih, S. (2016). The copigmentation of anthocyanin isolated from mangosteen pericarp (Garcinia mangostana L.) as natural dye for dye-sensitized solar cells (DSSC). IOP Conference Series: Materials Science and Engineering, 107, $012061 . \quad \mathrm{https} / / /$ doi.org/10.1088/1757-899X/107/1/012061

Oroian, M., Leahu, A., Dutuc, A. and Dabija, A. (2017). Optimization of total monomeric anthocyanin (TMA) and total phenolic content (TPC) extractions from red cabbage (Brassica oleracea var. capitata $f$. rubra): Response Surface Methodology versus Artificial Neural Network. International Journal of Food Engineering, 13(3), 20160036. https:// doi.org/10.1515/ijfe-2016-0036

Patras, A., Brunton, N.P., O'Donnell, C. and Tiwari, B.K. (2010). Effect of thermal processing on anthocyanin stability in foods; mechanisms and kinetics of degradation. Trends in Food Science and Technology, 21(1), 3-11. https://doi.org/10.1016/ j.tifs.2009.07.004

Sun, J., Bai, W., Zhang, Y., Liao, X. and Hu, X. (2011). Identification of degradation pathways and products of cyanidin-3-sophoroside exposed to pulsed electric field. Food Chemistry, 126(3), 1203-1210. https:// doi.org/10.1016/j.foodchem.2010.12.002

Türkyılmaz, M., Yemis, O. and Özkan, M. (2012). Clarification and pasteurisation effects on monomeric anthocyanins and percent polymeric colour of black carrot (Daucus carota L.) juice. Food Chemistry, 134(2), 1052-1058. https:// doi.org/10.1016/j.foodchem.2012.03.013

Wang, W., Jung, J., Tomasino, E. and Zhao, Y. (2016). Optimization of solvent and ultrasound-assisted extraction for different anthocyanin rich fruit and their effects on anthocyanin compositions. LWT Food Science and Technology, 72, 229-238. https:// doi.org/10.1016/j.lwt.2016.04.041

Zhang, Y., Tang, T., He, H., Wu, H., and Hu, Z. (2011). Influence of several postharvest processing methods on polyphenol oxidase activity and cichoric acid content of Echinacea purpurea roots. Industrial Crops and Products, 34(1), 873-881. https:// 
doi.org/10.1016/j.indcrop.2011.02.010

Zheng, X., Xua, X., Liu, C., Sun, Y., Lin, Z. and Liu, H. (2013). Extraction characteristics and optimal parameters of anthocyanin from blueberry powder under microwave-assisted extraction conditions. Separation and Purification Technology, 104(5), 1725. https://doi.org/10.1016/j.seppur.2012.11.011 